\title{
Knowledge and awareness on hepatitis B infection among adult population in some selected villages in Keranigonj, Dhaka, Bangladesh
}

\author{
M Shakil ${ }^{1 凶}$, MS Laskar², A Farhana ${ }^{3}$, AKMJ Alam $^{4}$, AU Alam ${ }^{5}$, W Islam ${ }^{6}$
}

\begin{abstract}
This cross sectional descriptive study was conducted among the rural people in some selected villages in Keraniganj upazila, Dhaka, Bangladesh from November 2015 to April 2016 to determine the knowledge and awareness about hepatitis B (HB) infection. The sample was collected using non-probability (purposive) method from the available people in the villages. The sample size was 200. The age most of the respondents were in the 26-35 age range; male respondents were higher than that of female and most of the respondents were married. The majority of respondents (60\%) had primary and secondary education level, $42 \%$ were housewife, $40 \%$ had monthly family income range at $5000-10000$ Taka, $45 \%$ had $>5$ persons in their family, $51 \%$ lived in pacca house, $52.5 \%$ drunk water from deep tube-well, and $82.5 \%$ did nothing for purification of water and $80 \%$ used sanitary latrine. The results of the study revealed that only $43.5 \%$ had knowledge on $\mathrm{HB}$ and $37.9 \%$ knew about HB from doctors. In case of mode of transmission, risk group and prevention of $\mathrm{HB}, 50.6 \%$ thought it is spread by water, $40.2 \%$ thought sex workers are more prone to develop HB and only $29 \%$ thought HB can be prevented by vaccination. This study indicates that there is a lack of awareness about HB, its route of transmission and modes of prevention among the rural people and appropriate measures are needed to increase correct awareness on HB for prevention purpose.
\end{abstract}

Key words: Awareness, hepatitis B, rural population, prevention, Bangladesh.

\section{Introduction}

Viral hepatitis is a serious public health problem affecting billions of people globally. Caused mainly by hepatitis viruses $A, B, C$, $D$ and $E$, and rarely by cytomegalovirus, Epstein-Barr virus and fungal infections, the spectrum of hepatitis range from sub-clinical to milder and life threatening illness including hepato-cellular carcinoma. Hepatitis B (HB) is a serious blood borne infection that affects the liver and caused by hepatitis $B$ virus (HBV). It is infectious and the most common cause of chronic hepatitis, liver cirrhosis and hepato-cellular carcinoma. ${ }^{1}$ Globally two billion people are infected with HBV, and millions of them have chronic (lifelong) infections that kill more than one million people globally each year. In the Middle East and Indian sub-continent, HBV infection is of intermediate endemicity with chronic HBV

1. M Shakil, MBBS, MPH, Asst. Prof. of Community Medicine, Army Medical College, Comilla. Email: mshakil1470@ gmail.com 2. MS Laskar, MD, MPH, PhD, Prof. of Community Medicine, Gazi Medical College, Khulna

3. A Farhana, MBBS, MPH, Asso. Prof. of Community Medicine, MH Samorita Medical College \& Hospital, Dhaka

4. AKMJ Alam, MBBS, MPH, Asst. Prof. of Community Medicine, Shahabuddin Medical College, Dhaka

5. MAU Alam, MBBS, DLO, Asst. Prof. of ENT, Eastern Medical College, Comilla

6. W Islam, MBBS, DCH, Asst. Prof. of Pediatrics, Ashiyan Medical College, Dhaka 
carriage rate of $2-5 \%$ among general population. ${ }^{2}$ Bangladesh is one of the most densely populated countries of the world with poor socioeconomic a hygienic conditions. The incidence of different kinds of liver diseases like hepatitis, cirrhosis and liver cancers is common in Bangladesh. About $4-7 \%$ of the population have $\mathrm{HB}$ and $1-3 \%$ have hepatitis $\mathrm{C}$. About $3.5 \%$ of pregnant women have HBV infection. It was reported in a study that $2.3 \%$ of girls in a school were diagnosed with $\mathrm{HB}^{3}$ It is shocking that about $70 \%$ of those living with liver disease are completely unaware of their illness.

Most of the liver diseases are preventable by awareness. The National Liver Foundation of Bangladesh is a non-profit organization started with the aim of prevention, treatment, education and research on liver diseases in Bangladesh. ${ }^{4} \mathrm{HB}$ was the first to be discovered in 1965 by Baruch Blumberg. Most people who were infected long ago with HBV or hepatitis $\mathrm{C}$ virus are unaware of their chronic infection and so can unknowingly transmit the infection to other people. HB, often referred to as the "secret killer," is the most dangerous type of viral hepatitis despite the dramatic increase in the treatment and effective vaccination against the disease. In Africa, the prevalence rate of $\mathrm{HB}$ was $10-15 \%$. The 2009 Ghana Health Service report released very scary figures suggesting an increase in the prevalence rate of $\mathrm{HB}$ from $8: 1$ in 2005 to $6: 1$ in $2009 .{ }^{5}$ This means one out of every sixth person is infected with the disease. There has also been an increase in the number of deaths associated with the disease. ${ }^{5}$

Two strategies are helpful for reducing HBV infection: first, case finding and targeted education and immunization for reducing vertical, sexual and household transmission, and second, universal vaccination and promotion of safe sex practices at community level. After graduating from high school, adolescents may go to college or start a job; in either case, they go to a more open social circumstance and would be more exposed to HBV.
It is obvious that for many diseases, having appropriate knowledge, attitude and practice may reduce the probability of disease acquisition among at risk populations. In reality, there is little knowledge about infectious diseases and acceptance of preventive measures could be improved by educating people. ${ }^{6}$ There have been several studies that evaluated the HBV knowledge of Asian minorities in the United States of America such as Vietnamese and Cambodians in Seattle and Vietnamese students in Massachusetts and according to the findings, the knowledge level of the studied subjects was mostly low. ${ }^{7,8}$ On the other hand, studies on Singaporean people showed that their knowledge was suitable. ${ }^{9,10} \mathrm{HBV}$ continues to be a major health problem in worldwide including Bangladesh. Vaccination against HBV is now introduced in the expanded programme on immunization. However, there is a large number of populations still not aware of hepatitis and its consequences.

Knowledge-surveys are representative of a specific population to collect information on what is known, believed and done in relation to a particular topic, and are the most frequently used study tool in health-seeking behavior research. Knowledge is usually assessed in order to determine how far community knowledge corresponds to biomedical concepts. If it is needed to deliver a good health service to mass people with limited facilities then awareness about the common diseases and involvement of the people in health care delivery system is an emergent part. This study was carried out to determine the level of knowledge and the vaccination coverage of $\mathrm{HB}$ virus in a rural population.

\section{Materials and Method}

This descriptive type of cross sectional study was conducted among rural people in Keraniganj upazila, Dhaka, Bangladesh from November 2015 to April 2016 to determine the knowledge and awareness about HB infection. The sample was collected purposively from the availability of the population, and data were collected by using a pretested a structured questionnaire. The sample size was 200 . The data 
Mediscope 2017;4(2):13-19

were processed and analyzed using Microsoft computer. Results were reported using descriptive statistics and expressed as percentage (\%) where appropriate.

Table 1. Socio-demographic characteristics of the respondents, $(n=200)$

\begin{tabular}{|c|c|c|}
\hline Characteristics & Group & $\%$ \\
\hline \multirow{5}{*}{ Age } & $\leq 25$ years & 26.5 \\
\hline & $26-35$ years & 30.5 \\
\hline & $36-45$ years & 20.5 \\
\hline & $46-55$ years & 12.5 \\
\hline & $\geq 56$ years & 10.0 \\
\hline \multirow{2}{*}{ Gender } & Male & 54.5 \\
\hline & Female & 45.5 \\
\hline \multirow{3}{*}{ Marital status } & Married & 78.5 \\
\hline & Unmarried & 19.0 \\
\hline & Widow & 2.5 \\
\hline \multirow{4}{*}{ Educational qualifications } & Illiterate & 29.0 \\
\hline & Primary & 32.0 \\
\hline & Secondary & 28.0 \\
\hline & $\begin{array}{r}\text { Higher secondary } \\
\text { and above }\end{array}$ & 11.0 \\
\hline \multirow{6}{*}{ Occupation } & Housewife & 42.0 \\
\hline & Service holder & 17.0 \\
\hline & Business & 16.0 \\
\hline & Farmer & 9.5 \\
\hline & Student & 6.0 \\
\hline & Others & 9.5 \\
\hline \multirow{4}{*}{ Monthly income } & $<5000$ Taka & 35.0 \\
\hline & 5000-10000 Taka & 40.0 \\
\hline & 10000-15000 Taka & 12.5 \\
\hline & $>15000$ Taka & 12.5 \\
\hline \multirow{2}{*}{ Family members } & $\leq 4$ persons & 45.5 \\
\hline & $>4$ persons & 54.5 \\
\hline \multirow{3}{*}{ Residence } & Pacca house & 51.0 \\
\hline & Kacha house & 25.0 \\
\hline & Semi pacca house & 24.0 \\
\hline \multirow{2}{*}{ Source of drinking water } & Deep tube-well & 52.5 \\
\hline & Tube-well & 47.5 \\
\hline \multirow{4}{*}{ Type of water purification } & Nothing & 82.5 \\
\hline & Boiling & 12.5 \\
\hline & Filtration & 4.0 \\
\hline & Others & 1.0 \\
\hline \multirow{3}{*}{ Type of latrine } & Sanitary latrine & 80.0 \\
\hline & Service type & 19.5 \\
\hline & Open field & 0.5 \\
\hline
\end{tabular}

Results

Table 1 shows that the most of the respondents were in the 26-35 age range; male respondents were higher than that of 


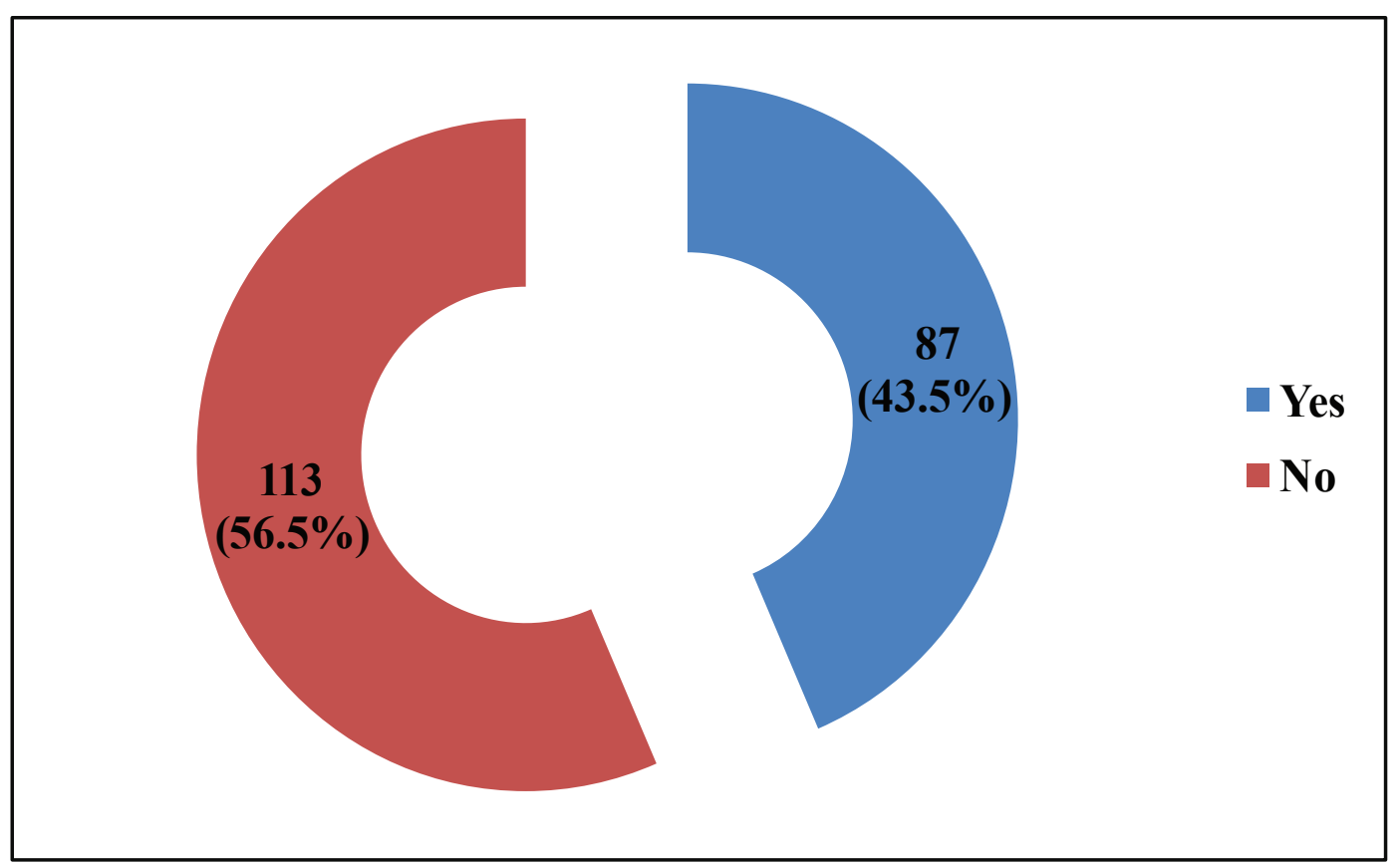

Fig. 1. Distribution of the respondents whether they knew about HB or not, $(n=200)$.

Table 2. Respondents according to the source of HB information, $(n=87)$

\begin{tabular}{lrr}
\hline $\begin{array}{l}\text { Source of know- } \\
\text { ledge about HB }\end{array}$ & Number & $\mathbf{\%}$ \\
\hline Doctor & 33 & 37.9 \\
Health Assistant & 22 & 25.3 \\
Friend & 5 & 5.7 \\
Neighbor & 6 & 6.9 \\
Kobiraj & 3 & 3.4 \\
Media & 18 & 20.8 \\
\hline Total & 87 & 100.0 \\
\hline
\end{tabular}

female and most of the respondents were married. The majority of respondents $(60.0 \%)$ had primary and secondary education level, $42.0 \%$ were housewife, $40.0 \%$ had monthly family income range at 5000-10000 Taka, 45\% had >4 persons in their family, $51.0 \%$ lived in pacca house, $52.5 \%$ drunk water from deep tube-well, and $82.5 \%$ did nothing for purification of water and $80.0 \%$ used sanitary latrine.

Fig. 1 shows that according to their knowledge about HB, most of the respondents (113, $56.5 \%$ ) did not know about HB.
Table 3. Distribution of the respondents by their knowledge about mode of transmission of $\mathrm{HB},(n=87)$

\begin{tabular}{lrr}
\hline Mode of transmission & Number & $\mathbf{\%}$ \\
\hline By blood & 35 & 40.2 \\
By water & 44 & 50.6 \\
By touch & 2 & 2.3 \\
By air & 1 & 1.2 \\
By multiple use of syringe & 3 & 3.4 \\
By sexual activity & 2 & 2.3 \\
\hline Total & 87 & 100.0 \\
\hline
\end{tabular}

Table 2 shows that according to the source of knowledge about $\mathrm{HB}$, the proportion of the respondents knew about HB from doctor, health assistant, media, neighbor, friend and kobiraj was $37.9 \%, 25.3 \%, 20.8 \%, 6.9 \%$, $5.7 \%$ and $3.4 \%$, respectively.

Table 3 shows that according to their knowledge about HB transmission, the proportion of respondents knew about HB transmission by water, blood, multiple use of syringe, touch, sexual activity and air was $50.6 \%$, $40.2 \%, 3.4 \%, 2.3 \%, 2.3 \%$ and $1.2 \%$, respectively. 


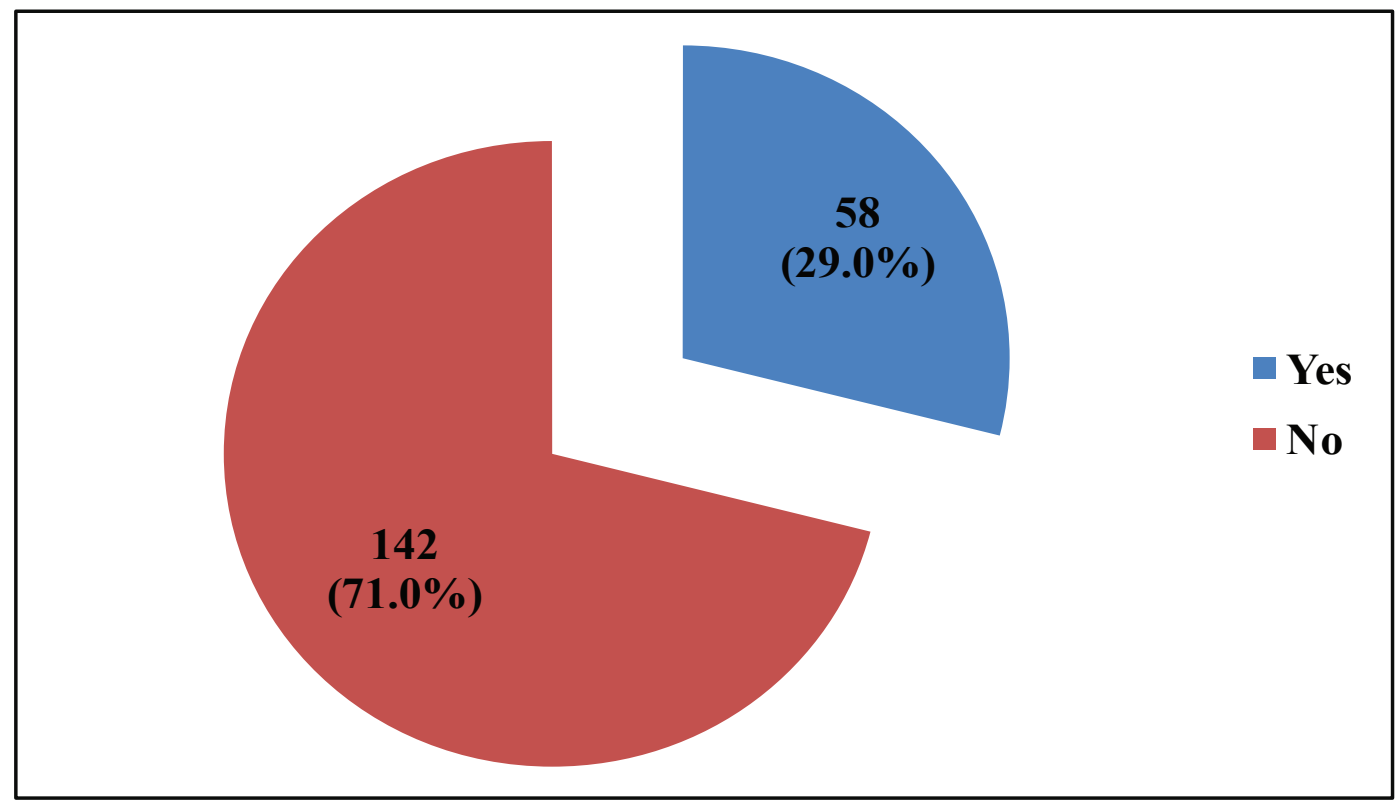

Fig.2. Distribution of the respondents whether they thought HB is preventable or not, $(n=200)$.

Table 4. Distribution of the respondents according to their knowledge about high risk group of $\mathrm{HB},(n=87)$

\begin{tabular}{lrr}
\hline $\begin{array}{l}\text { Knowledge about } \\
\text { high risk group }\end{array}$ & Number & $\mathbf{\%}$ \\
\hline Doctor & 1 & 1.2 \\
Health Assistant & 2 & 2.3 \\
Sex worker & 35 & 40.2 \\
Drug abuser & 29 & 33.3 \\
Driver & 5 & 5.7 \\
Working abroad & 8 & 9.2 \\
Others & 7 & 8.1 \\
\hline Total & 87 & 100.0 \\
\hline
\end{tabular}

Fig. 2 shows that according to their knowledge about prevention of $\mathrm{HB}$, most of the respondents $(142,71.0 \%)$ did not think that HB is preventable, only $58(29.0 \%)$ of them thought.

Table 4 shows that according to their knowledge about high risk group to develop HB, the proportion of respondents knew about high risk groups as sex worker, drug abuser, working abroad, others, driver, health assistant and doctor was $40.2 \%, 33.3 \%, 9.2 \%, 8.1 \%, 5.7$, $2.3 \%$ and $1.2 \%$, respectively.
Table 5. Distribution of the respondents according to their knowledge about mode of prevention of $\mathrm{HB},(n=58)$

\begin{tabular}{lrr}
\hline $\begin{array}{l}\text { Knowledge about } \\
\text { Mode of prevention }\end{array}$ & Number & $\%$ \\
\hline By vaccination & 32 & 55.2 \\
By safe sex & 5 & 8.6 \\
By safe drinking water & 19 & 32.8 \\
Others & 2 & 3.4 \\
\hline Total & 58 & 100.0 \\
\hline
\end{tabular}

Table 5 shows that according to their knowledge about HB prevention, $55.2 \%$ of the respondents thought $\mathrm{HB}$ is preventable told that it can be prevented by vaccination, followed by safe drinking water $(32.8 \%)$, by safe sex (8.6\%) and others (3.4\%).

\section{Discussion}

$\mathrm{HB}$ is the world's most common blood borne viral infection, accounting for 2 billion infections, 350 million carriers and 6 lakh deaths annually. The virus is transmitted mainly by blood, and the complications of infection are chronic hepatitis, cirrhosis, and hepatocellular carcinoma. Approximately 100 million HB carriers, more than $5.6 \%$ of the total 
$\mathrm{HB}$ is the world's most common blood borne viral infection, accounting for 2 billion infections, 350 million carriers and 6 lakh deaths annually. The virus is transmitted mainly by blood, and the complications of infection are chronic hepatitis, cirrhosis, and hepato-cellular carcinoma. Approximately 100 million HB carriers, more than $5.6 \%$ of the total population, live in the member countries of the World Health Organization SouthEast Asia Region. ${ }^{11,12}$ More than 300000 people are estimated to die each year due to the chronic consequences of $\mathrm{HB}$, particularly cirrhosis and liver cancer. It has been clearly documented that HBV is far more infectious than human immunodeficiency virus in occupational health care settings.

Fortunately, HBV infection is largely preventable by vaccination. Transmission of infection is rare in persons who have been immunized. ${ }^{13}$ The general characteristics of the respondent in this study revealed that The age most of the respondents were in the 26-35 age range; male respondents were higher than that of female and most of the respondents were married. The majority of respondents $(60.0 \%)$ had primary and secondary education level, $42.0 \%$ were housewife, $40.0 \%$ had monthly family income range at 5000-10000 Taka, $45.0 \%$ had $>5$ persons in their family, $51.0 \%$ lived in pacca house, $52.5 \%$ drunk water from deep tube-well, and $82.5 \%$ did nothing for purification of water and $80.0 \%$ used sanitary latrine.

The results of the study revealed that only $43.5 \%$ of the respondents had knowledge on $\mathrm{HB}$, whereas the rate of knowledge on $\mathrm{HB}$ was $53.8 \%$ in nursing college students in Tamil Nadu, India, and $59.2 \%$ of the students of Rural Dental College, Maharashtra, India had correct knowledge on HB infection. ${ }^{13-15}$

According to the source of knowledge about $\mathrm{HB}$, the proportion of the respondents knew about HB from doctor, health assistant, media, neighbor, friend and kobiraj was $37.9 \%, 25.3 \%, 20.8 \%, 6.9 \%, 5.7 \%$ and $3.4 \%$, respectively. In a study, Misra et al found that source of information regarding HB included television (75.0\%), newspapers $(55.0 \%)$, and radio $(26.0 \%){ }^{16}$ According to their knowledge about HB transmission, the proportion of respondents knew about HB transmission by water, blood, multiple use of syringe, touch, sexual activity and air was $50.6 \%, 40.2 \%, 3.4 \%, 2.3 \%, 2.3 \%$ and $1.2 \%$, respectively; whereas $71.0 \%$ of the nursing students in Tamil Nadu, India had correct knowledge about mode of transmission.14 Another study conducted among the students of University of Kassala, Sudan reported poor knowledge on causative agents and mode of transmission. ${ }^{17}$

In this study, according to knowledge about high risk group to develop HB, the proportion of respondents knew about high risk groups as sex worker, drug abuser, working abroad, others, driver, health assistant and doctor was $40.2 \%, 33.3 \%, 9.2 \%, 8.1 \%, 5.7$, $2.3 \%$ and $1.2 \%$, respectively. Most of the respondents $(71.0 \%)$ did not think whether $\mathrm{HB}$ is preventable, only $29.0 \%$ of thought that it is preventable. According to their knowledge about HB prevention, $55.2 \%$ of the respondents thought that $\mathrm{HB}$ is preventable told that it can be prevented by vaccination, followed by safe drinking water $(32.8 \%)$, by safe sex $(8.6 \%)$ and others $(3.4 \%)$. A study carried out among the nursing students in Tamil Nadu, India showed that $69.3 \%$ had correct knowledge that it is a vaccine preventable disease. ${ }^{14}$

This study indicates that there is a lack of awareness about $\mathrm{HB}$, its route of transmission and modes of prevention among the rural people and appropriate measures are needed to increase correct awareness on HB for prevention purpose.

\section{References}

1. Mesfin YM, Kibert KT. Assessment of knowledge and practice towards hepatitis 
$B$ among medical and health science students in Haramaya University, Ethiopia. PLoS ONE 2013;8(11):e79642.

2. Ashraf $\mathrm{H}$, Alam $\mathrm{NH}$, Rothermundt $\mathrm{C}$, et al. Prevalence and risk factors of hepatitis $B$ and $C$ virus infections in an impoverished urban community in Dhaka, Bangladesh. BMC Infect Dis 2010;10:208.doi:10.1186/ 1471-2334-10-208.

3. Laskar MS, Harada N, Khan F. Prevalence of hepatitis B surface antigen (HBsAg) in Viqarunnessa Noon Girls' School children in Dhaka, Bangladesh. Cent Eur J Public Health 1997;5(4):202-4.

4. National Liver Foundation, Bangladesh. 2016.

5. Ghana Health Service. Annual ReportGhana Health Services, 2009. Available at: http://www.ghanahealthservice.org/.../ Final_Draft_2009_GHS_Annual_Report $\% 20 f i n a l \%$ final.

6. Akumiah PO, Sarfo LA. Assessing the level of awareness on viral hepatitis among educated people. Appl Res J 2015;1(2):45-56.

7. Taylor VM, Jackson JC, Chan N, Kuniyuki A, Yasui Y. Hepatitis B knowledge and practices among Cambodian American women in Seattle, Washington. J Community Health 2002;27(3):151-63.

8. Taylor VM, Choe JH, Yasui Y, Li L, Burke $\mathrm{N}$, Jackson JC. Hepatitis B awareness, testing, and knowledge among Vietnamese American men and women. J Community Health 2005;30(6):477-90.

9. Lu W, Mak B, Lim SG, Aung MO, Wong $\mathrm{ML}$, Wai CT. Public misperᄀceptions about transmission of hepatitis $B$ virus in Singapore. Ann Acad Med Singapore
2007;36(10):797-800.

10.Wai CT, Mak B, Chua W, et al. Mispercep $\neg$ tions among patients with chronic hepatitis B in Singapore. World J Gastroenterol 2005;11(32):5002-5.

11.Sweety KN, Mimi SA. Awareness of hepatitis $B$ vaccination in rural area: a survey. J Curr Adv Med Res 2014;1(1):3-7.

12.Roushan N, Toosi MN, Meysamie A, Esteghamati AR, Hajrassuliha $\mathrm{H}$. Hepatitis B knowledge among Iranian adolescents: a national survey. Iran Red Crescent Med J. 2013;15(12):e11558.

13. Sujatha P, Sudha KS. Assessment of knowledge regarding hepatitis $B$ among medical students in Rangaraya Medical College, Kakinada, Eastgodavari District, Andhra Pradesh. IJIMS 2014;1(7):45-7.

14.Swarnalatha N. Do nursing students know about hepatitis B? A study from nursing college in Tamil Nadu. Int $\mathrm{J}$ Health Rehabil Sci 2014;3(2):69-74.

15.Saini R, Saini S, Sugandha RS. Knowledge and awareness of hepatitis B infection amongst the students of Rural Dental College, Maharashtra, India. Ann Nigerian Med 2010;4:18-20.

16.Misra B, Panda C, Das HS, Nayak KC, Singh SP. Study on awareness about hepatitis B viral infection in coastal Eastern India. Hepatitis B Annual 2009; 6(1):19-28.

17.Khalid FA, Eltayeb AA, Elbadawi NEE. Awareness and knowledge of hepatitis $B$ and HIV/AIDS among the University of Kassala Students, Sudan. J AIDS Clin Res 2013;4:194.doi:10.4172/2155-6113. 1000194.

\section{Suggestion for citation of the above:}

Shakil M, Laskar MS, Farhana A, Alam AKMJ, Alam AU, Islam W. Knowledge and awareness on hepatitis $B$ infection among adult population in some selected villages in Keranigonj, Dhaka, Bangladesh. Mediscope 2017;4(2):13-9. 